\title{
Lobectomy versus total thyroidectomy in differentiated thyroid carcinoma: A
}

\section{review}

\author{
Ibrahim Altedlawi Albalawi ${ }^{1}$, Hyder Osman Mirghani ${ }^{2}$
}

1. Department of Surgery, Faculty of Medicine, University of Tabuk, Kingdom of Saudi Arabia

2. Department of Internal Medicine, Faculty of Medicine, University of Tabuk, Kingdom of Saudi Arabia

\section{Corresponding Author:}

Ibrahim Altedlawi Albalawi

Department of Surgery, Faculty of Medicine, University of Tabuk, Kingdom of Saudi Arabia

Email: drbalawi@yahoo.com

\section{ABSTRACT}

\section{Background}

Thyroid cancer is on the rise globally, there is increasing adoption of lobectomy for low-risk differentiated thyroid cancer.

\section{Aims}

The current review aimed to assess lobectomy versus total thyroidectomy in low-risk differentiated thyroid carcinoma.

\section{Methods}

A systematic electronic search was conducted in the Pub Med and Google Scholar with no limitation of the period, 85 articles published in English were retrieved, two researchers screened the abstract for removal of duplications. Twentyone articles fulfilled the inclusion and exclusion criteria.

\section{Results}

Among the twenty-one articles included (more than twothirds were retrospective), eleven were from the USA, two from Europe, six from Asia, one from Canada and one from Australia. The results were mixed, some preferred lobectomy, others were on the side of total thyroidectomy, while some advised to weigh the risks and benefits.

\section{Conclusion}

The results were mixed regarding the mode of surgery in low-risk differentiated thyroid cancer. Further, welldesigned studies are needed to solve the current controversy.

\section{Key Words}

Lobectomy, total thyroidectomy, low risk, differentiated thyroid carcinoma

\section{What this review adds:}

\section{What is known about this subject?}

There is an increasing use of lobectomy for low-risk differentiated thyroid carcinoma.

\section{What new information is offered in this review?}

The increasing rate of lobectomy in differentiated thyroid carcinoma may be not justified in all patients, both the patient's risks and the aggressiveness of the tumour need to be considered.

3. What are the implications for research, policy, or practice?

An improvement of thyroid surgery for low-intermediate risk differentiated thyroid cancer by proper patients stratification before thyroid surgery.

\section{Introduction}

The incidence of thyroid carcinoma is on the rise with a great contribution from microcarcinoma $(<1 \mathrm{~cm})$. The tumour size criteria for lobectomy have been widened to 1$4 \mathrm{~cm}$. Thus, there is increasing use of lobectomy versus total thyroidectomy, the American Thyroid Association recommend lobectomy for low-risk differentiated thyroid cancer, however thyroxine replacement is needed in the majority of patients to suppress thyroid-stimulating hormone (TSH) $<2 \mathrm{mlU} / \mathrm{ml}$ to suppress the proliferation of thyroid cancer cell. A recent study including 1521 patients with low risk differentiated thyroid cancer and followed for 
more than five years showed that the level of TSH did not affect tumour recurrence in the short-term following lobectomy. ${ }^{1,2}$ Total thyroidectomy in differentiated thyroid carcinoma is recommended only for aggressive tumours, those with local invasion or distant metastasis. However, the extent of thyroid surgery in tumours measuring $1 \mathrm{~cm}$ remains controversial. The current review aimed to assess lobectomy versus total thyroidectomy among low-risk differentiated thyroid cancer measuring $<4 \mathrm{~cm}$.

\section{Methodology}

\section{The search strategy and article selection:}

A systematic search was conducted in Pub Med and Google Scholar databases for relevant articles. All article published in the English language during the period from the first published article to August 2019 were eligible.

\section{Inclusion and exclusion criteria:}

All articles comparing lobectomy and total thyroidectomy during the stated period in English were included; articles in languages other than the English language were not included. A total of 85 studies were identified through the database search, 60 full-text articles were assessed for eligibility: only 21 studies fulfilled the inclusion and exclusion criteria, the name of the author, year of publication, type of study, the number of patients included, and the results were reported. The excel was used for data analysis. The different phases of the systematic review were reported (Figure 1).

\section{Results}

A total of 21 studied were included (eleven were from the USA, two from Europe, six from Asia, one from Canada and one from Australia). There were 15 retrospective studies, two prospective, three reviews, and one comparative survey. The studies included 280871 patients. The results were inconclusive, some studies preferred lobectomy, others were on the side of total thyroidectomy, while some advised to weigh the risks and benefits (Table 1 ). ${ }^{3}$

\section{Discussion}

In the current review, Shah et al. ${ }^{4}$ showed that lobectomy (Lb) and total thyroidectomy (TT) are similar for low-risk patients, Santini and colleagues ${ }^{5}$ in their review stated that the risks and hazards should be weighed when considering lobectomy and total thyroidectomy, Zerey et al. ${ }^{6}$ included 13,854 patients with well-differentiated thyroid carcinoma and showed that Complete thyroidectomy is associated with increased morbidity, total charges, and length of hospital stay, similarly Kuo et al. ${ }^{7}$ showed no survival benefits of TT versus lobectomy in follicular thyroid microcarcinoma and Hurthle cell microcarcinoma $(<1 \mathrm{~cm})$, Lee et al. ${ }^{8}$ assessed papillary microcarcinoma and concluded similar observations. In the current review, Adams et al. ${ }^{9}$ studied papillary thyroid carcinoma (PTC) measuring $1-4 \mathrm{~cm}$ and showed no survival benefit of TT versus lobectomy, Megwalu et al. ${ }^{10}$ from the USA studied 203 patients with microfollicular carcinoma and showed no survival benefits, Kluijfhout et al. ${ }^{11}$ studied1000 low-risk well-differentiated thyroid cancer $1-4 \mathrm{~cm}$ in Canada and recommended to weigh the risks and benefits of surgery, Aburjania et al. ${ }^{12}$ assessed 68 encapsulated form of follicular variant of papillary thyroid cancer $v s$. the nonencapsulated variant and stated that the encapsulated variant may be managed more conservatively, Kuba et al. ${ }^{13}$ studied 173 patients with 1 to $5 \mathrm{~cm}$ stage $\mathrm{cNO}$ and $\mathrm{CMO}$ PTC in Japan and concluded equivalent prognosis of TT vs. lobectomy, Kim et al. ${ }^{14}$ studied thyroid microcarcinoma and showed similar observations. Mainthia et al. ${ }^{15}$ investigated 1335 noninvasive encapsulated follicular variant of papillary thyroid carcinoma and showed that the impact on the extent of surgery is limited, Gartland et al. ${ }^{16}$ studied of PTC measuring $1-4 \mathrm{~cm}$ and showed similar results. Liu et al. and de Rienzo-Madero et al. ${ }^{17,18}$ showed the advantage of lobectomy versus TT. On the other hands Doi et al. ${ }^{19}$ from Australia showed Improved outcomes in TT and postsurgical ablation, while Leiker et al. ${ }^{20}$ concluded the cost effectiveness of TT, Ebina et al. ${ }^{21}$ assessed 1187 patients with PTC $>1 \mathrm{~cm}$ and concluded that Low-risk patients possessing risk factors for distant recurrence would be likely to benefit from total thyroidectomy followed by radioactive iodine, Macedo et al. ${ }^{22}$ in their meta-analysis concluded lower mortality in TT for unilateral $(\leq 1 \mathrm{~cm})$ PTC in Rajjoub et al. $^{23}$ assessed 33,816 of conventional papillary thyroid cancer vs. follicular-variant papillary thyroid cancer and showed total thyroidectomy improved survival for conventional PTC $(2.3 .9 \mathrm{~cm})$ but not $1-1.9 \mathrm{~cm}$. Equivalent outcomes for follicular variant PTC, Benjamin and colleagues $^{24}$ investigated 114/562 low-risk thyroid carcinoma patients and concluded that TT recommended due to high contralateral lobe involvement.

\section{Conclusion}

The current review showed mixed results with some preferred lobectomy, others were on the side of total thyroidectomy, while some advised to weigh the risks and benefits, randomized controlled trials are needed to solve the issue.

\section{References}

1. Cox C, Bosley M, Southerland LB, et al. Lobectomy for treatment of differentiated thyroid cancer: can patients 
avoid postoperative thyroid hormone supplementation and be compliant with the American Thyroid Association guidelines? Surgery. 2018;163(1):75-80. doi: 10.1016/j.surg.2017.04.039.

2. Lee MC, Kim MJ, Choi HS, et al. Postoperative ThyroidStimulating Hormone Levels Did Not Affect Recurrence after Thyroid Lobectomy in Patients with Papillary Thyroid Cancer. Endocrinol Metab (Seoul). 2019;34(2):150-157. doi: 10.3803/EnM.2019.34.2.150.

3. McDow AD, Pitt SC. Extent of Surgery for Low-Risk Differentiated Thyroid Cancer. Surg Clin North Am. 2019;99(4):599-610. doi: 10.1016/j.suc.2019.04.003.

4. Shah JP, Loree TR, Dharker D, et al. Lobectomy versus total thyroidectomy for differentiated carcinoma of the thyroid: a matched-pair analysis. Am J Surg. 1993;166(4):331-5.

5. Santini J, Haddad A. Total thyroidectomy is the recommended treatment for all Papillary Thyroid Carcinoma (PTC). Acta Otorhinolaryngol Belg. 1999;53(3):161-4.

6. Zerey M, Prabhu AS, Newcomb WL, et al. Short-term outcomes after unilateral versus complete thyroidectomy for malignancy: a national perspective. Am Surg. 2009;75(1):20-4.

7. Kuo EJ, Roman SA, Sosa JA. Patients with follicular and Hurthle cell microcarcinomas have compromised survival: a population level study of 22,738 patients. Surgery. 2013;154(6):1246-54.

doi: 10.1016/j.surg.2013.04.033

8. Lee J, Park JH, Lee CR, et al. Long-term outcomes of total thyroidectomy versus thyroid lobectomy for papillary thyroid microcarcinoma: comparative analysis after propensity score matching. Thyroid. 2013;23(11):140815. doi: 10.1089/thy.2012.0463.

9. Adam MA, Pura J, Gu L, et al. Extent of surgery for papillary thyroid cancer is not associated with survival: an analysis of 61,775 patients. Ann Surg. 2014;260(4):601-7. doi: 10.1097/SLA.0000000000000925.

10. Megwalu UC, Green RW. Total Thyroidectomy Versus Lobectomy for the Treatment of Follicular Thyroid Microcarcinoma. Anticancer Res. 2016;36(6):2899-902.

11. Kluijfhout WP, Pasternak JD, Lim J, et al. Frequency of High-Risk Characteristics Requiring Total Thyroidectomy for 1-4 cm Well-Differentiated Thyroid Cancer. Thyroid. 2016;26(6):820-4. doi: 10.1089/thy.2015.0495.

12. Aburjania Z, Jang S, Montemayor-Garcia C, et al. Encapsulated follicular variant of papillary thyroid cancer: are these tumors really benign?. J Surg Res. 2017;216:138-142. doi: 10.1016/j.jss.2017.04.020.

13. Kuba S, Yamanouchi K, Hayashida N, et al. Total thyroidectomy versus thyroid lobectomy for papillary thyroid cancer: Comparative analysis after propensity score matching: A multicenter study. Int J Surg. 2017;38:143-148. doi: 10.1016/j.ijsu.2016.09.083.

14. Kim SK, Park I, Woo JW, et al. Total thyroidectomy versus lobectomy in conventional papillary thyroid microcarcinoma: Analysis of 8,676 patients at a single institution. Surgery. 2017;161(2):485-492. doi: 10.1016/j.surg.2016.07.037.

15. Mainthia R, Wachtel $H$, Chen $Y$, et al. Evaluating the projected surgical impact of reclassifying noninvasive encapsulated follicular variant of papillary thyroid cancer as noninvasive follicular thyroid neoplasm with papillarylike nuclear features. Surgery. 2018;163(1):60-65. doi: 10.1016/j.surg.2017.04.037.

16. Gartland RM, Lubitz CC. Impact of Extent of Surgery on Tumor Recurrence and Survival for Papillary Thyroid Cancer Patients. Ann Surg Oncol. 2018;25(9):2520-2525. doi: 10.1245/s10434-018-6550-2.

17. Liu J, Zhang $\mathrm{Z}$, Huang $\mathrm{H}$, et al. Total thyroidectomy versus lobectomy for intermediate-risk papillary thyroid carcinoma: A single-institution matched-pair analysis. Oral Oncol. 2019;90:17-22. doi: 10.1016/j.oraloncology.2019.01.010. Epub 2019 Jan 31

18. de Rienzo-Madero B, Sabra JP, Gand E, et al. Unilateral benign multinodular versus solitary goiter: Long-term contralateral reoperation rates after lobectomy. Surgery. 2019;165(1):75-79. doi: 10.1016/j.surg.2018.04.074..

19. Doi SA, Engel JM, Onitilo AA. Total thyroidectomy followed by postsurgical remnant ablation may improve cancer specific survival in differentiated thyroid carcinoma. Clin Nucl Med. 2010;35(6):396-9. doi: 10.1097/RLU.0b013e3181db4db4.

20. Leiker AJ, Yen TW, Cheung K, et al. Cost analysis of thyroid lobectomy and intraoperative frozen section versus total thyroidectomyin patients with a cytologic diagnosis of "suspicious for papillary thyroid cancer". Surgery. 2013;154(6):1307-14. doi: 10.1016/j.surg.2013.06.031.

21. Ebina A, Sugitani I, Fujimoto $Y$, et al. Risk-adapted management of papillary thyroid carcinoma according to our own risk group classification system: is thyroid lobectomy the treatment of choice for low-risk patients? Surgery. 2014;156(6):1579-89. doi: 10.1016/j.surg.2014.08.060.

22. Macedo FI, Mittal VK. Total thyroidectomy versus lobectomy as initial operation for small unilateral papillary thyroid carcinoma: A meta-analysis. Surg Oncol. 2015;24(2):117-22. doi: 10.1016/j.suronc.2015.04.005.

23. Rajjoub SR, Yan $H$, Calcatera NA, et al. Thyroid lobectomy is not sufficient for $\mathrm{T} 2$ papillary thyroid 
cancers. Surgery. 2018;163(5):1134-1143. doi: 10.1016/j.surg.2017.12.026

24. Benjamin J, Hephzibah J, Cherian AJ, et al. Is hemithyroidectomy adequate in low risk differentiated thyroid cancer? World J Nucl Med. 2019;18(2):171-175. doi: 10.4103/wjnm.WJNM_70_18.

\section{ACKNOWLEDGEMENTS}

We would like to acknowledge Dr. Yasin Ibrahim, Assistant Prof. Of Community Medicine for reviewing the current manuscript

\section{PEER REVIEW}

Not commissioned. Externally peer reviewed.

\section{CONFLICTS OF INTEREST}

The authors declare that they have no competing interests.

\section{FUNDING}

The research is self-funded and not supported financially by any institute or organization

\section{ETHICS COMMITTEE APPROVAL}

The ethical committee of the Medical College, University of Tabuk approved the research (Ref. Number, READ, 0049) 
Figure 1: Flow diagram through the different phases of the systematic review(PRISMA flowchart)
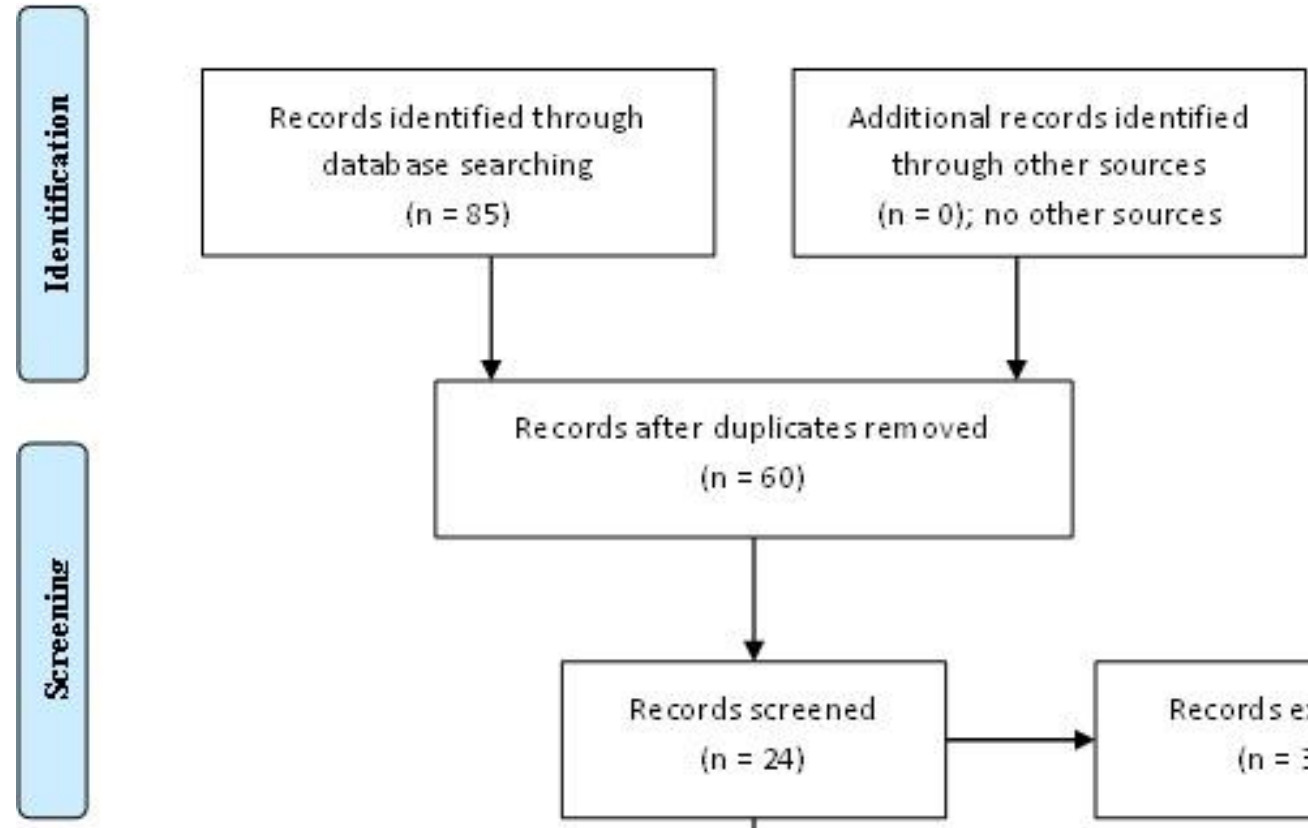

Records after duplicates removed

$$
(n=60)
$$
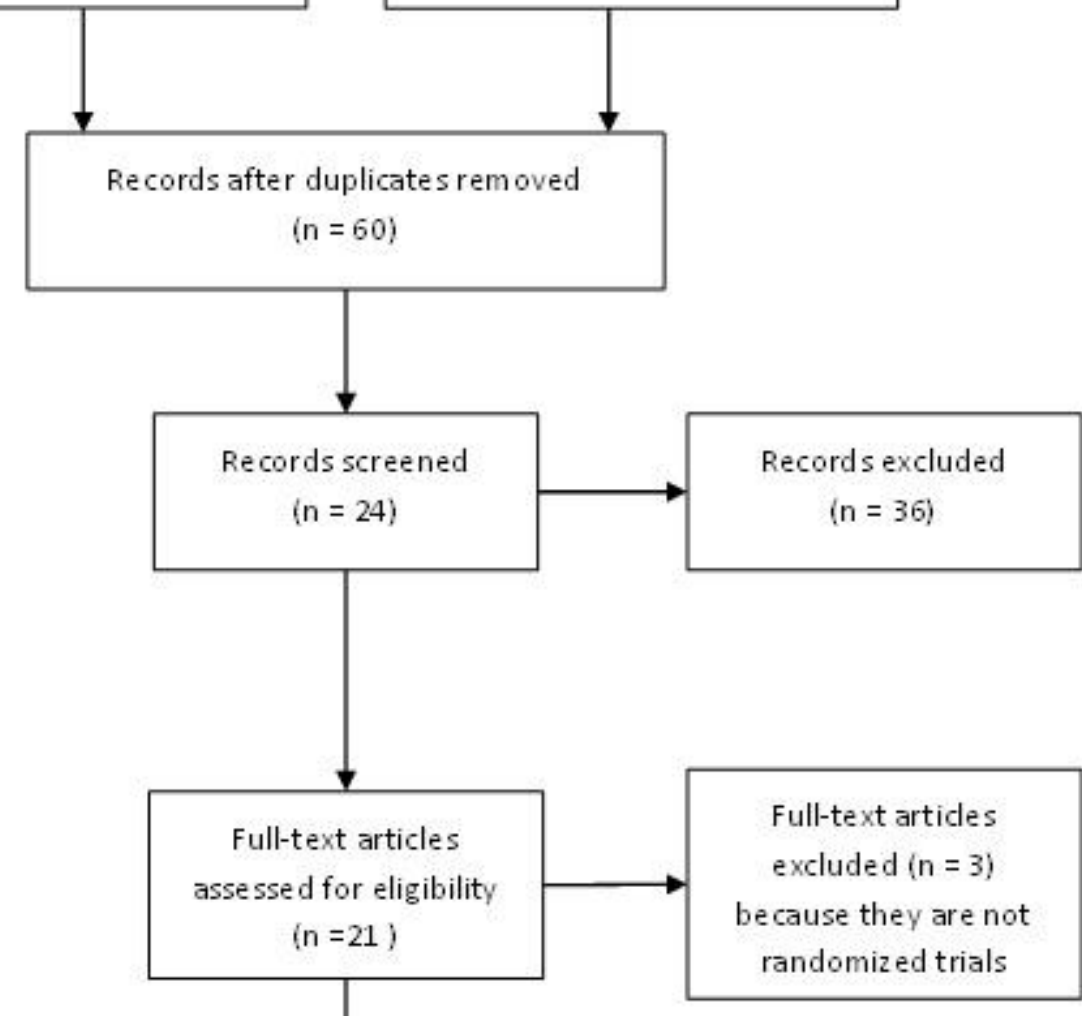

Studies included in the qualitative synthesis ( $n=21$ ) 
Table 1: Lobectomy versus total thyroidectomy in differentiated thyroid carcinoma

\begin{tabular}{|c|c|c|c|c|c|}
\hline author & year & country & type & patients & result \\
\hline Shah et al. & 1993 & USA & Prospective & 931 patients & $\begin{array}{l}\text { Low-risk patients } \\
\text { undergoing lobectomy are likely } \\
\text { to do as well as those } \\
\text { undergoing total thyroidectomy }\end{array}$ \\
\hline Santini et al. & 1999 & France & Review & & Weigh the risks and hazards \\
\hline Zerey et al. & 2009 & USA & Retrospective & $\begin{array}{l}13,854 \text { patients } \\
\text { of well- } \\
\text { differentiated } \\
\text { carcinoma }\end{array}$ & $\begin{array}{l}\text { Complete thyroidectomy is } \\
\text { associated with increased } \\
\text { morbidity, total charges, and } \\
\text { length of stay }\end{array}$ \\
\hline Doi et al. & 2010 & Australia & Retrospective & 614 PTC patients & $\begin{array}{l}\text { Improved outcomes in TT and } \\
\text { post-surgical ablation }\end{array}$ \\
\hline Leiker et al. & 2013 & USA & Retrospective & & TT is more cost-effective \\
\hline Kuo et al. & 2013 & USA & Retrospective & $\begin{array}{l}564 \\
\text { follicular thyroid } \\
\text { microcarcinoma } \\
\text { and Hurthle cell } \\
\text { microcarcinoma } \\
(<1 \mathrm{~cm})\end{array}$ & No survival benefits \\
\hline Lee et al. & 2013 & South Korea & $\begin{array}{l}\text { Comparative } \\
\text { analysis }\end{array}$ & $\begin{array}{l}2014 \text { papillary } \\
\text { microcarcinoma }\end{array}$ & $\begin{array}{l}\text { Death and locoregional } \\
\text { recurrence were similar in } \\
\text { patients with PTMC who } \\
\text { underwent LT with CCND and } \\
\text { those who underwent TT with } \\
\text { central compartment node } \\
\text { dissection. }\end{array}$ \\
\hline Ebina et al. & 2014 & Japan & Retrospective & $\begin{array}{l}1187 \text { patients } \\
\text { with } \text { PTC }>1 \mathrm{~cm}\end{array}$ & $\begin{array}{l}\text { Low-risk patients possessing risk } \\
\text { factors for distant recurrence } \\
\text { would be likely to benefit from } \\
\text { total thyroidectomy followed by } \\
\text { radioactive iodine }\end{array}$ \\
\hline Adam et al. & 2014 & USA & Retrospective & $\begin{array}{l}61,775 \text { PTC } 1- \\
4 \mathrm{~cm}\end{array}$ & $\begin{array}{l}\text { No survival benefits, Older age, } \\
\text { male sex, black race, lower- } \\
\text { income, tumor size, and } \\
\text { presence of nodal or distant } \\
\text { metastases were independently } \\
\text { associated with compromised } \\
\text { survival }\end{array}$ \\
\hline Macedo et al. & 2015 & USA & A meta-analysis & $\begin{array}{l}\text { unilateral }(\leq 1 \\
\mathrm{cm}) \text { PTC }\end{array}$ & $\begin{array}{l}\text { Inconclusive, lower mortality in } \\
\mathrm{TT} \text {, consider other factors } \\
\text { including multifocality, } \\
\text { locoregional involvement, mode } \\
\text { of presentation and age at } \\
\text { diagnosis }\end{array}$ \\
\hline Megwalu et al. & 2016 & USA & Retrospective & $\begin{array}{l}203 \\
\text { microfollicular } \\
\text { carcinoma }\end{array}$ & $\begin{array}{l}\text { No survival benefit of TT over } \\
\text { lobectomy }\end{array}$ \\
\hline Kluijfhout et al. & 2016 & Canada & Retrospective & $\begin{array}{l}1000 \text { low-risk } \\
\text { well- } \\
\text { differentiated } \\
\text { thyroid cancer } 1 \text { - } \\
4 \mathrm{~cm}\end{array}$ & $\begin{array}{l}\text { Completion TT recommended in } \\
43 \% \text {, balance the relative } \\
\text { benefits, risks, and costs of } \\
\text { initial TT versus the possible } \\
\text { need for preoperative } \\
\text { completion TT }\end{array}$ \\
\hline Aburjania et al. & 2017 & USA & Prospective & $\begin{array}{l}68 \text { encapsulated } \\
\text { form of follicular } \\
\text { variant of }\end{array}$ & $\begin{array}{l}\text { The encapsulated variant can be } \\
\text { managed more conservatively }\end{array}$ \\
\hline
\end{tabular}




\begin{tabular}{|c|c|c|c|c|c|}
\hline & & & & $\begin{array}{l}\text { papillary thyroid } \\
\text { cancer vs. the } \\
\text { nonencapsulated } \\
\text { variant }\end{array}$ & \\
\hline Kuba et al. & 2017 & Japan & retrospective & $\begin{array}{l}173 \text { patients } \\
\text { with } 1-\text { to } 5-\mathrm{cm} \\
\text { stage cN0 and } \\
\text { cM0 PTC }\end{array}$ & $\begin{array}{l}\text { Equivalent prognosis of TT vs. } \\
\text { lobectomy }\end{array}$ \\
\hline Kim et al. & 2017 & South Korea & retrospective & $\begin{array}{l}\text { 8,676 thyroid } \\
\text { microcarcinoma }\end{array}$ & $\begin{array}{l}\text { lobectomy may be a safe } \\
\text { operative option for select } \\
\text { patients with papillary thyroid } \\
\text { microcarcinoma without } \\
\text { multifocality }\end{array}$ \\
\hline Gartland et al. & 2018 & USA & $\begin{array}{l}\text { Review of PTC } \\
\text { measuring } 1-4 \mathrm{~cm}\end{array}$ & 6 & $\begin{array}{l}\text { Comparable outcomes of } \\
\text { lobectomy and thyroidectomy }\end{array}$ \\
\hline Rajjoub et al. & 2018 & USA & Retrospective & $\begin{array}{l}33,816 \text { of } \\
\text { conventional } \\
\text { papillary thyroid } \\
\text { cancer vs. } \\
\text { follicular-variant } \\
\text { papillary thyroid } \\
\text { cancer }\end{array}$ & $\begin{array}{l}\text { Total thyroidectomy improved } \\
\text { survival for conventional PTC } \\
(2.3 .9 \mathrm{~cm}) \text { but not } 1-1.9 \mathrm{~cm} \text {. } \\
\text { Equivalent outcomes for } \\
\text { follicular variant PTC }\end{array}$ \\
\hline Mainthia et al. & 2018 & USA & Retrospective & $\begin{array}{l}1335 \\
\text { noninvasive } \\
\text { encapsulated } \\
\text { follicular variant } \\
\text { of papillary } \\
\text { thyroid cancer to } \\
\text { noninvasive } \\
\text { follicular thyroid } \\
\text { neoplasm with } \\
\text { papillary-like } \\
\text { nuclear features }\end{array}$ & $\begin{array}{l}\text { The impact on the extent of } \\
\text { surgery is limited }\end{array}$ \\
\hline Liu et al. & 2019 & China & Retrospective & $\begin{array}{l}4230 \\
\text { intermediate risk } \\
\text { PTC }\end{array}$ & $\begin{array}{l}\text { No advantage of total } \\
\text { thyroidectomy over lobectomy }\end{array}$ \\
\hline $\begin{array}{l}\text { de Rienzo- } \\
\text { Madero B et al. }\end{array}$ & 2019 & France & Retrospective & $\begin{array}{l}2675 \text { patients } \\
\text { with a single } \\
\text { nodule or } \\
\text { unilateral } \\
\text { multinodular } \\
\text { goiter }\end{array}$ & $\begin{array}{l}\text { Lobectomy is the treatment of } \\
\text { choice }\end{array}$ \\
\hline James et al. & 2019 & USA & Retrospective & 44,537 & $\begin{array}{l}\text { The incidence } \\
\text { of total thyroidectomy has not } \\
\text { decreased despite } \\
\text { recommendations encouraging } \\
\text { consideration of lobectomy for } \\
\text { patients with small papillary } \\
\text { thyroid cancers }\end{array}$ \\
\hline Benjamin et al. & 2019 & India & Retrospective & $\begin{array}{l}\text { 114/562 low-risk } \\
\text { thyroid } \\
\text { carcinoma } \\
\text { patients }\end{array}$ & $\begin{array}{l}\text { TT recommended due to high } \\
\text { contralateral lobe involvement }\end{array}$ \\
\hline
\end{tabular}

